\title{
Where are the Bachelor Canvasbacks?
}

By D. P. Olson, University of Minnesiatia, St. Paul
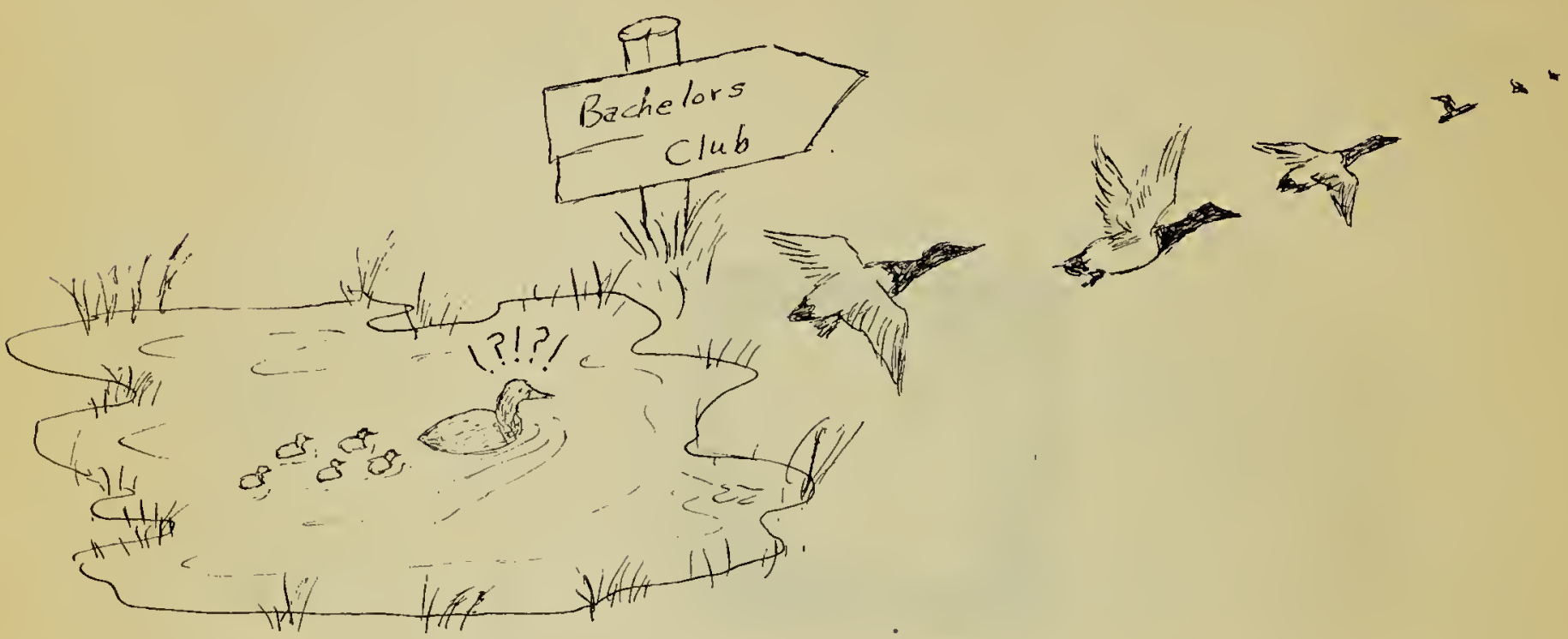

The Canvasbacks will be returning to their prairie breeding grounds in early April. When they first arrive and courting activity is high, they are easily observed, and you may ibe puzzled as you count them to find that there are alcout two males to every female. This imbalance is confirmed by a large number of observations from Maryland to Manitoba, although the reason for it is not clear.

Males which find mates remain with the females until laying is completed, then leave. Unsuccessful males may be seen for a short time on the breeding marsheis, but they soon leave, apparently not to return until the next breeding season. By July, breeding marshes contiain hens with broods, but few, if any, drake Canvasibacks.

Duck hunters in breeding areas usually kill three adult females and six juveniles for every adult male. What has become of the adult males w'e see in spring, and why don't hunters bag more males when males are actually twice as numerous? These are questions that waterfowl biologists are seeking to aniswer.

Some clues to this mystery are already available. Frequently in summer, large numbers of Canvasbacks are seen on the more remote lakes and marshes. Last summer an airplane check on one of these areas indicated that about $80 \%$ were adult males. It is not known wheiher these are flocks of successful males, un- successful males, or both, nor when they arrive, how long they remain, or whether they molt there.

Recently, techniques have been worked out which permit biologisits to sex and age the ducks in hunters' bags by examining one wing which the hunter cuts off and saves. Checks on waterfowl bagged last fall by hunters in several prairie areas showed that fewer males than females are taken. This suggests that the male migrates differently. Some males, however, are present in the concentrations of juveniles and hens that ga:her on large marshes in laite summer. One such concentration contained about thirty per cent adult males, but the Canvasbacks which huniters harvested from this concentration included only ten per cent adult males. The reason for this bias against hens and juveniles are yet to be determined. Hunter bag checks from scme areas away from the breeding grounds indicate that male Canvasbacks are killed in excezs of females, and this may tend to offset the low male kill on the breading grounds.

It is hoped that waterfowl harvest information will be improved by using the wing technique. During the next two years biologists from the University of Minnesota and the Delta Waterfowl Research Station will be studying Canvasback poipulations. In addition to field studies on the breeding grounds, they will analyse as many sex ratio observa- 
tions and examine as many Canvasback wings as can be obtained. Persons who would like to make sex ratio counts or save wings from fall shot Canvasbacks are urged to contact the Delta Waterfowl Research Station, Delta, Manitoba.

\section{UNUSUAL NEST SITES OF AMERICAN ROBIN AND SLATE- COLORED JUNCO.-On May 9,} 1958, in Maurice Alcock's farmyard $2 \frac{1}{2}$ miles northeast of Ponirilias, Sask., I was surprised to see a female American Robin fly out from the 2inch opening of a 45 imperial gallon barrel lying on its side in a highwheeled farm wagon. The wagon box had a plank bottom and 12-inoh sides, with the ends open. The end of the barrel was approximately 8 inches from the end of the plank bottom, so this afforded the robin a landing shelf, with the barrel opening slightly to the right of boticm centre and about 4 inches above the shelf. Seen through the 2 -inch opening, one-third of the nest was visible, the larger portion being to the left. The nest was incomplete, with the mud lining only' about one-third complete. The wagon and barrel were moved the same day, and the nesting disrupted. It seems strange that the robin chose the barrel insiead of a more natural nesting site in the thick grove of trees surrounding the farm yard, or the farm buildings.

On June 1, 1958, near Nipawin, I found a Slate-coloned Junco also nesiting in a metal container. The nest was in a 1/2-pound tobacco clan lying on its side, in the centre of a clearing in a scattered sitand of jackpine and small white poplar. The can wals partially imbedded in the ground, about $1 / 6$ filled with pine needles and leaf mould. The front of the can had tipped slightly downward, thus affording complete protection from the elements for the nest. The nest contained 3 eggs of the Brown-headed Cowblird and 3 of its host.-Maurice Street, Nipawin.

MOCKINGBIRD IN SASKATOON. -For a fleeting moment in July and for about five minutes on October 14 I saw a Mockingibird reminding me of my native New Hampshire. The Mockingbird became a regular visitor to my yard in November but it was killed by a cat on December 9, 1958.-Lillian Headley, Saskatoon.
CARDINAL AT KELWOOD. - I have lived here on a farm clicse to the Riding Mountains since 1911. During the summer of 1958 I had the pleasure of seeing my first Cardinal with his brilliant red coat and crested head. We saw him quite often during the summer but now, December 30 , we see him every day. He seems quite at home in our snowy shelterbelt and I hope he survives the winter.-W. F. 'Rosenbarker, Kelwood, Manitoba.

SAW-WHET RARE VISITOR. Glen Fox, Kindersley, reports as a "rare visitor" to the area a Saw-whet Owl seen Jan. 16, 1959. His last previous observation of one was in the winter of 1955-56 when a Saw-whet was found dead along with a Richardison's Owl. Also described as an "unusual visitor" by Frank Brazier, Regina, was the Saw-whet which he observed in the Legislative Park, Jan. 11, 1959. At 3.00 p.m. the bird Was photogiraphed by R. W. Fyfe 20 feet up in a spruce where Brazier had found it at 10.45 a.m. The owl ejected a pellet, then began to feed on prey it had evidently held all this lime (but which coulid not be seen because the owl's feet were hidden by a bough). The recovered pelle: contiained a redpoll skull, and two feathers which floated down wilen the owl was eating appeared to be redpoll feathers. Two other records of the Saw-whet (Lumsden, Skull Creek) will be noted in the report of the Christmas Count.

\section{S.N.H.S. SUMMER MEETING}

Moose Mountain Prov. Park June $13-14,1959$

Reservations for the annual meeting should be made early with the Parks Manager, Moose Mountain Provincial Park, Carlyle, Sask. Chalet rooms: $\$ 2.50-$ $\$ 4.50$ per day; non - modern cabins: $\$ 3.50-\$ 4.50 \quad(2-6$ persons); modern cabins: $\$ 6.50-$ $\$ 9.00$ (4-6 persons). Meals will be served at the Chalet at Kenosee, our headquarters for the weekend. Programme chairnan: C. Ellis, 820 Valley View Drive, Moose Jaw. 